\title{
MEMAHAMI MODAL VERBA SHOULD DAN MUST MELALUI PEMBELAJARAN KONTEKSTUAL
}

\author{
Arief Baskoro $^{1}$, I.G.A. Lokita Purnamika Utami ${ }^{1}$, Ni Made Sri Ayu Hartini ${ }^{2}$ \\ Universitas Pendidikan Ganesha, Indonesia ${ }^{1}$, \\ SMP Negeri 1 Singaraja, Indonesia ${ }^{2}$ \\ Ariefbaskoro1319@gmail.com;lokitapurnamika@unidksha.ac.id; \\ sriayu_h@yahoo.com
}

\begin{abstract}
ABSTRAK
Penelitian ini bertujuan untuk meningkatkan kemampuan siswa dalam menggunakan modal verbaShoulddan Must dalam berbagai konteks menggunakan CTL (Contextual Teaching Learning). Penelitian ini diterapkan pada siswa kelas VIII A7 SMP Negeri 1 Singaraja tahun Ajaran 2018/2019 yang terdiri dari 32 Siswa. Melalui observasi awal diketahui bahwa siswa memiliki masalah dalam menggunakan modal verba should dan must. Penelitian ini merupakan Penelitian Tindakan Kelas (PTK) yang dilakukan dalam dua siklus. Instrumen yang digunakan adalah tes ( pre-test dan post test I dan post-test II), dan lembar pengamatan. Hasil penelitian ini menunjukan adanya peningkatan dalam kemampuan menggunakan should dan mustyang mampu mancapai KKM (78) pada akhir siklus kedua. Hasil rata-rata skor meningkat dari 44,68 (pre-test) ke 54,84 ( post test 1 ) dan 80,93 (post test 2). Persentasi kelulusan siswa juga meningkat dari observasi awal ke post test I (siklus I) dan post test II (siklus II)
\end{abstract}

Kata kunci: CTL,Modal verb,berbagai konteks..

\begin{abstract}
This study aimed to improve students' ability in using modal verba "must and should" in various context through CTL. The subject of this study was the students of class VIIIA7 Negeri 1 Singaraja academic year 2018/2019 which consisted of 32 students. The study was made based on the preliminary observation which indicated that students had problem in using modal verba "must and should". The type of the study was Classroom Action Research and conducted on two cycles. Each cycle divided into planning, action, observation, and reflection. The intruments used on this research were tests (pre-test, post test I, post test 2) and observation sheet. The result showed improvement in students' speaking skill and achievement in passing the standart score (78) on the second cycle. The mean score improved from 44,68 (pre-test) into 54,84 (post test 1) and 80,93 (post test 2). The class percentage shows the improvement from preliminary observation to post test I (Cycle I) to post test II (cycle II)
\end{abstract}

Keywords: CTL, Modal verb, various context.. 


\section{PENDAHULUAN}

Saat ini, bahasa memainkan peran yang sangat penting dalam kehidupan manusia. Bahasa biasanya digunakan untuk berkomunikasi dengan orang lain. Ada banyak bahasa yang dapat digunakan oleh orang-orang untuk berkomunikasi dengan orang lain tetapi, bahasa paling populer yang digunakan oleh orang untuk berkomunikasi dengan orang lain di era ini adalah bahasa Inggris. Bahasa Inggris memainkan peran yang sangat penting di era ini. Hal ini dapat dilihat dalam berbagai aspek seperti teknologi, hiburan, pendidikan, dan aspek lainnya. Hal inilah yang menyebabkan mengapa bahasa Inggris juga dikenal sebagai bahasa internasional.

Untuk menguasai bahasa Inggris, siswa harus menguasai empat keterampilan dasar bahasa Inggris dan komponen bahasa. Keempat keterampilan dasar bahasa Inggris adalah mendengarkan, membaca, berbicara, dan menulis. Sementara itu, komponen bahasa adalah kosa kata, tata bahasa, dan pelafalan. Sebagai salah satu komponen bahasa, tata bahasa harus dikuasai oleh siswa karena tata bahasa memungkinkan mereka untuk menggunakan bahasa secara akurat. Tanpa tata bahasa yang benar, hampir tidak bisa menyusun kata-kata menjadi kalimat, kalimat menjadi paragraf dan paragraf ke dalam sebuah bagian .

Menurut Ur (1988) grammar secara kasar didefinisikan sebagai cara bahasa memanipulasi dan menggabungkan kata untuk membentuk unit makna yang lebih panjang. Ada banyak aspek yang harus dipelajari oleh siswa dalam tata bahasa seperti kalimat struktur. Ini terdiri dari subjek dan kata kerja. Salah satu jenis kata kerja adalah modal bantu. Studi tentang modal bantu digunakan untuk mengungkapkan makna kewajiban, saran, larangan, dan lain-lain.

Berdasarkan hasil penelitian awal di SMP N 1 singaraja, ditemukan bahwa siswa kelas VIIII masih membuat beberapa kesalahan dalam menggunakan kata kerja bantu modal terutama Should dan Must. Kemampuan mereka masih dianggap rendah karena belum mencapai skor 78 (tujuh puluh delapan) sebagai kriteria penguasaan minimal atau Kriteria Ketuntasan Minimal (KKM). 
Berdasarkan pretest yang dilakukan di 8A7 pada hari Senin, 10 September2018, sebagian besar siswa tidak mampu memenuhi Kriteria Ketuntasan Minimal (KKM). Data menunjukkan bahwa nilai rata-rata pre-tes adalah 44,68 ada 4 siswa yang memperoleh skor di atas kriteria minimum penguasaan (KKM) sementara 28 siswa lainnya berada di bawah kriteria tersebut. Bahkan perlu disampaikan bahwa pencapaian terendah memperoleh skor 2 . Berdasarkan hasil kalkulasi persentase siswa yang lulus KKM adalah 12,5\%. Hal ini dianggap tidak cukup baik, sehingga bisa disimpulkan siswa kelas 8A7 memiliki masalah dalam penggunaan modal bantushould dan must

Kajian literature tentang modal bantu verba menemukan bahwa Modals dan semi modal berdasarkan makna dapat dikelompokkan ke dalam lima kategori (Swan, 1982). Katgori ini meliputi makna yang mengacu pada makna kepastian, kemungkinan, probabilitas lemah, kebiasaan, dan kemungkinan bersyarat

Untuk memecahkan masalah siswa, penulis mencoba mencari solusi atau cara yang tepat untuk meningkatkan kemampuan siswa dalam menggunakan modal bantu verba terutama penggunaan Should dan Must. Berdasarkan hasil kajian menyeluruh ditemukan bahwa metode Contextual Teaching and Learning (CTL) sangat baik untuk meningkatkan kemampuan bahasa siswa. Menurut Johnson (2006) CTL adalah proses pembelajaran yang bertujuan untuk membantu siswa melihat makna dalam subjek akademik dengan konteks kehidupan seharihari mereka, yang dengan konteks keadaan pribadi, sosial, dan budaya mereka.Nurhadi (2015) menyatakan bahwa pengajaran secara kontekstual memungkinkan siswa untuk memperkuat, memperluas, dan menerapkan pengetahuan dan keterampilan akademik mereka dalam berbagai pengaturan di sekolah dan di luar sekolah untuk memecahkan masalah di dunia nyata.

Berdasarkan pemaparan diatas maka penelitian ini bertujuan untuk melihat penggunaan CTL dalam meningkatkan kemampuan siswa menggunakan modal bantu verba Should dan Must. Rumusan masalah yang ingin di jawab dalam penelitian ini adalah "Dapatkah pembelajaran kontekstual meningkatkan kemampuan siswa dalam menggunakan kata kerja modal Should dan Must dalam berbagai konteks?" 


\section{KAJIAN PUSTAKA}

\section{Pengertian CTL (Contextual Teaching Learning)}

Satriani, Emilia dan Gunawan (2012) mendefinisikan kontekstual mengajar dan belajar sebagai sebuah pembelajaran filosofi yang menekankan minat dan pengalaman siswa. DefinisiCTL muncul dari penelitian yang dilakukan oleh The Office of Vocational and Adult Education sebagaimana dikutip dalam Berns dan Erickson (2001) adalah sebagai berikut. Pengajaran Contextual adalah sebuah konsep mengajar dan belajar yang menghubungkan materi pelajaran konten ke situasi dunia nyata; dan memotivasi siswa untuk membuat koneksi antara pengetahuan dan aplikasinya untuk hidup mereka sebagai anggota keluarga, warga, dan pekerja dan terlibat dalam kerja keras yang dibutuhkan pembelajaran. Oleh karena itu, dapat disimpulkan bahwa CTL adalah pendekatan yang menghubungkan materi untuk pengalaman siswadan aplikasi di dunia nyata mereka di luar kelas.

Dengan menerapkan CTL murid-murid dapat melihat relevansi materi yang mereka pelajari di kelas dengan penerapannya dikehidupan sehari-hari mereka.

\section{Prinsip-prinsip CTL}

Ada tujuh prinsip yang seharusnya dikembangkan oleh guru dalam menerapkan CTL (Ruhimat, dkk, 2012): (1) konstruktivisme, (2) penyelidikan, (3) bertanya, (4) komunitas belajar, (5)pemodelan, (6)refleksi, (7) penilaian autentik. Konstruktivisme dapat membantu siswa memahami materi yang telah mereka pelajari dalam waktu lama. Brown (2001) menyatakan bahwa, pembelajaran yang bermakna adalah pembelajaran yang menambah informasi baru ke dalam struktur yang ada dalam sistem memori, dan menghasilkan hubungan asosiasi yang menciptakan retensi yang lebih kuat.

Penyelidikan mendorong siswa untuk mengembangkan pengetahuan berdasarkan pengalaman mereka. Inkuiri dapat membantu siswa mengembangkan 
kreativitas dan pemikiran kritis. Siswa melakukan observasi, mengusulkan ide, membuat pertanyaan, membuat prediksi, mengumpulkan dan menghitung data, dan membuat kesimpulan dari apa yang telah mereka pelajari.

Kegiatan bertanya memberi manfaat dalam mengajar dan proses pembelajaran, seperti: (1) siswa dapat memperoleh banyak informasi; (2) guru bisamemeriksa pemahaman siswa; (3) mengembangkan respon siswa; (4) meningkatkan keingintahuan siswa; (5) mengamati pengetahuan awal siswa; (6) mendapatkan perhatian siswa; (7) mengundang pertanyaan dari para siswa; (8) meninjau siswa pengetahun siswa sebelumnya.

Komunitas belajar membiasakan siswa untuk bekerja secara kooperatif dengan orang lain dan berbagi pengetahuan mereka. Melalui komunitas belajar siswa dapat belajarcara bekerja dalam tim dan cara berinteraksi dengan orang lain. Karenanya, siswa bisa mendapatkannya informasi dari komunitas di dalam dan kelas luar, seperti keluarga atau masyarakat.

Pemodelan memberikan siswa model yang penting untuk membantu siswa memperoleh pengetahuan. Guru memberikan siswa model pengucapan. Dalam kegiatan dialog guru memberika contoh bagaimana menampilkan dialog yang diharapkan.

Refleksi dapat membimbing siswa menerapkan pengetahuan, sikap, dan keterampilan mereka dalam kehidupan nyata mereka. Mereka diajarkan memahami apa yang sudah dipelajari dan memikirkan bagaimana aplikasi di dunia nyata.

Penilaian autentik dilakukan selama dan pada akhir proses pembelajaran. Guru menunjukkan materi akademik yang diketahui siswa dan apa yang sudah bisa dilakukan siswa. Melalui penilaian autentik guru bisa melihat kemampuan siswa yang ssungguhnya.

\section{METODOLOGI PENELITIAN}

Penelitian ini merupakan sebuah Penelitian Tindakan Kelas.Penelitian tindakan kelas adalah penelitian yang digunakan untuk memecahkan masalah tertentudi suatu kelas atau sekolah, meningkatkan pengajaran dan strategi 
pendidikan lainnya atau membuat keputusan pada tingkat tertentu (Santrock, 2004). Berdasarkan penjelasan di atas, tepatlah penggunaan PTK sebagai desain penelitian untuk menganalisis masalah belajar dan juga menemukan solusinya.

Subjek penelitian ini adalah kelas VIII A7 di SMP N 1 Singaraja pada tahun akademik 2018/2019 dengan total mahasiswa 32 sebagai peserta utama.

Penelitian ini diadakan selama bulan September-Oktober 2018 dengan menggunakan Model dari Kurt Lewin sebagaimana dikutip oleh Arikunto ( 2009: 21).

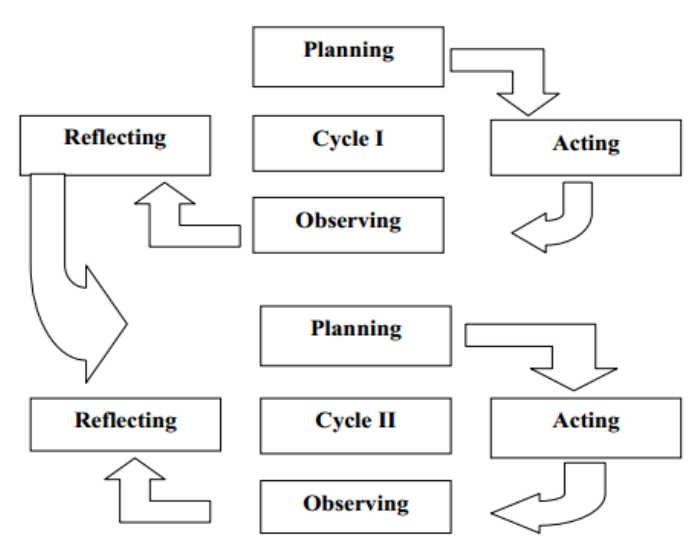

Gambar 3.1: Action Research Spiral, Model dari Kurt Lewin

(Arikunto, 2009: 21)

Model penelitian PTK ini terdiri dari empat tahap dalam melakukan penelitian ini menggunakan desain Kurt Lewin seperti perencanaan, tindakan, observasi, dan refleksi sebagaimana dapat dilihat pada Gambar 3.1.

Dalam mengumpulkan data, peneliti menggunakan dua teknik pengumpulan data, yaitu; data kualitatif dan data kuantitatif. Data kualitatif didapat melalui observasi, kuesioner. Sementara itu, data kuantitatif didapat melalui hasil pre-test dan post-test I dan post test II. Tabel 1 menampilakn hubungan antara rumusan masalah dan metode pengumpulan data, instrument dan analisis yang digunakan dalam penelitian ini 
Tabel 1. Instrumen dan Analisis

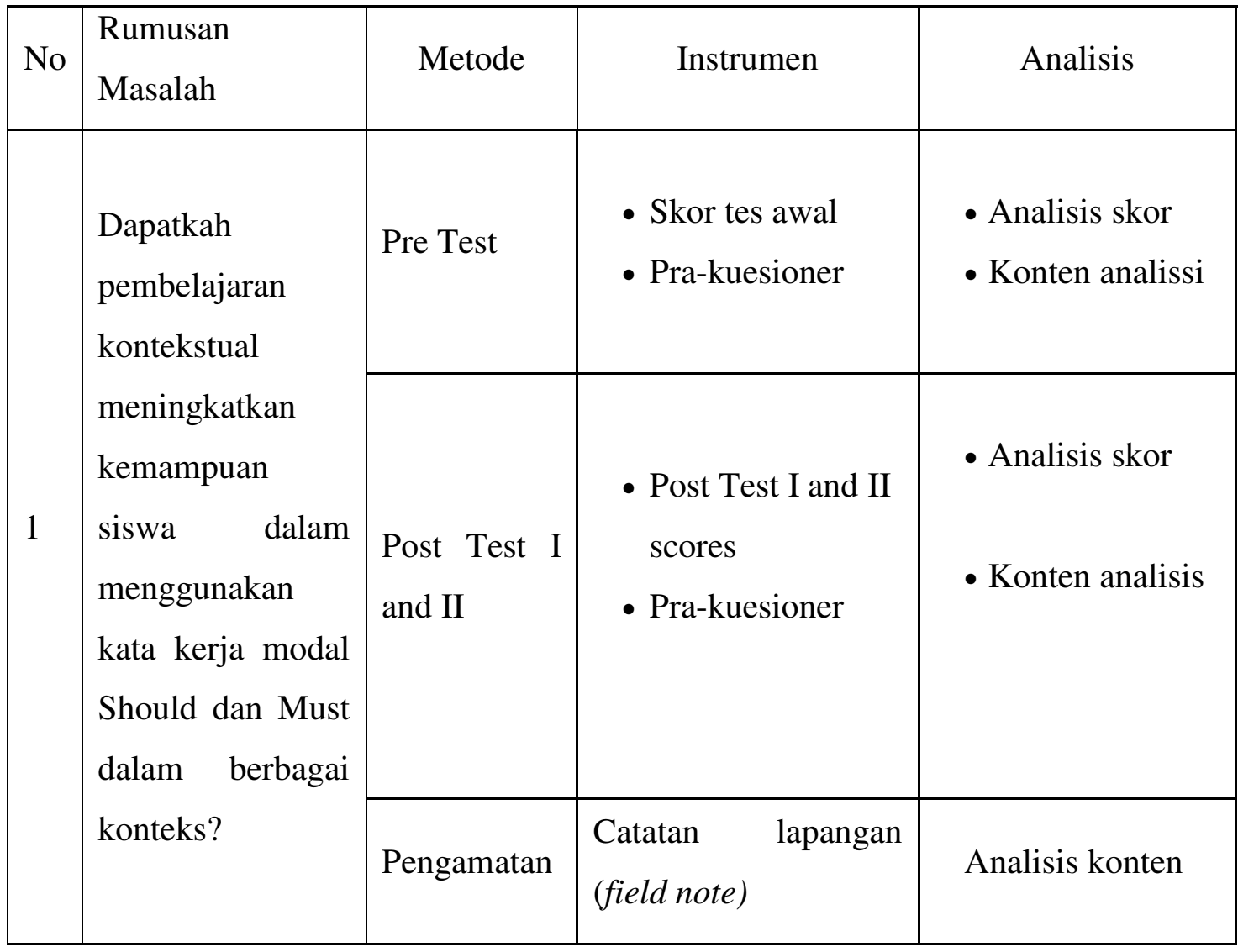

Perhitungan analisis data dalam mencari skor rata - rata menggunakan beberapa komponen, yaitu rata - rata ( $\mathrm{X})$, jumlah siswa (n), dan skor individu (x) menggunakan rumus :

$$
X=\frac{\sum X}{n}
$$


Sedangkan dalam menghitung presentase hasil test siswa siswa, penulis akan menggunakan tiga komponen perhitungan, yaitu persentase kelas $(\mathrm{P})$, persentase total Skor (F), dan jumlah siswa (n) dengan rumus:

$P=\frac{F x}{n} \times 100 \%$

Perhitungan prestasi siswaakan dilakukan dengan menggunakan beberapa elemen seperti persentase siswa peningkatan $(\mathrm{P})$, hasil pre-test $(\mathrm{y})$, dan hasil posttest (y1) menggunakan rumus:

$P=\frac{Y 1-Y}{y} \times 100 \%$

Penelitian ini dihentikan jika mencapai target penelitian. Target penelitian ini adalah $70 \%$ siswa dapat mencapai target skor (KKM) yaitu nilai 78 .

\section{HASIL DAN PEMBAHASAN}

Bagian ini akan berkaitan dengan deskripsi data di setiap tahap, yang terdiri dari temuanobservasi awal, temuan siklus I dan temuan siklus II.

\section{Temuan Observasi Awal}

Sebelum melakukan penelitian, peneliti meminta siswa untuk mengisi sebuah kuesione awal. Kuesioner awal ini dilakukan untuk mengetahui tanggapan siswa tentang kemampuan mereka memahami tata bahasa Bahasa Inggris dan harapan mereka tentang model pembelajaran tata bahasa. Kuesioner yang digunakan dalam penelitian ini adalah kuesioner terbuka. Kuesioner diberikan kepada siswa pada Senin, 10 September 2018. Hasil kuesioner menunjukkan bahwa 78\% siswa menyatakan mengalami kesulitan dalam memahami aturan tata bahasa Bahasa Inggris dan $82 \%$ menyatakan pembelajaran tata bahasa lebih baik dibuat lebih menarik dan mudah dipahami.Menurut hasil pra-kuesioner dapat disimpulkan bahwa tanggapan siswa dalam belajar bahasa Inggris tidak baik. Sebagian besar dari mereka tidak suka belajar tata bahasa Inggris karena mereka menilai tata bahasa Inggris sebagai bahan kompleks. Oleh karena itu, sebagian 
besar dari mereka memiliki motivasi yang rendah dalam mempelajari tata bahasa Inggris. Akibatnya, masalah-masalah tersebut mempengaruhi pemahaman mereka dalam belajar modal bantu 'wajib' dan 'harus'. Sebagian besar dari mereka merasa sulit untuk memahami penggunaan dan rumus dari kata kerja bantu modal should danmust.

Selain kuesioner, peneliti juga melakukan pre-test pada tahap Observasi Awal. Pre-test ini merupakan soal pilihan ganda berjumlah 10 soal tentang penggunaan modal bantu verba should dan must. Pre-test dilakukan Senin, 10 September 2018. Tabel 3 menampilkan hasil pre test

Tabel 3. Hasil pre-test penggunaan modal verbashould dan must

\begin{tabular}{|l|l|l|l|}
\hline $\begin{array}{l}\text { Nomor } \\
\text { siswa }\end{array}$ & $\begin{array}{l}\text { Skor } \\
\text { Pretest }\end{array}$ & $\begin{array}{l}\text { Nomor } \\
\text { siswa }\end{array}$ & $\begin{array}{l}\text { Skor } \\
\text { Pretest }\end{array}$ \\
\hline S 1 & 70 & S 17 & 10 \\
\hline S 2 & 30 & S 18 & $80^{*}$ \\
\hline S 3 & 50 & S 19 & $80^{*}$ \\
\hline S 4 & 40 & S 20 & 30 \\
\hline S 5 & 60 & S 21 & 40 \\
\hline S 6 & 60 & S 22 & 40 \\
\hline S 7 & 40 & S 23 & 30 \\
\hline S 8 & 60 & S 24 & 50 \\
\hline S 9 & 50 & S 25 & $80 *$ \\
\hline S 10 & 30 & S 26 & 10 \\
\hline S 11 & 10 & S 27 & 40 \\
\hline S 12 & 40 & S 28 & 40 \\
\hline S 13 & 60 & S 29 & 20 \\
\hline S 14 & 10 & S 30 & 40 \\
\hline S 15 & $80 *$ & S 31 & 70 \\
\hline S 16 & 10 & S 32 & 70 \\
\hline
\end{tabular}




\begin{tabular}{|l|l|}
\hline Rata-rata & 44,68 \\
\hline
\end{tabular}

Berdasarkan hasil pre-test pada tabel, diketahui bahwa nilai rata-rata pretes adalah 44,68. Terdapat 4 siswa yang memperoleh skor di atas kriteria minimum mastery (KKM) sedangkan 28 siswa lainnya memperoleh skor di bawah kriteria tersebut. Selanjutnya, persentase siswa yang lulus KKM adalah 12,5\%. Dari analisis itu, dapat dilihat bahwa hampir dari kata kerja tata bahasa tata bahasa delapan siswa Should dan Must masih rendah.

\section{Temuan Siklus I}

Pelaksanaan Penelitian Tindakan Kelas dalam penelitian ini terdiri dari siklus I dan siklus 2. Setiap siklus dibagi menjadi empat bagian mulai dari perencanaan, tindakan, observasi, dan refleksi. Tindakan siklus pertama dilakukan pada tanggal 12 September 2018. Pada bagian ini, peneliti menerapkan rencana pelajaran seperti yang telah dibuat pada tahap sebelumnya. Pada bagian ini, peneliti juga melakukan posttest untuk siklus I.

Pada fase ini, peneliti membuat perencanaan untuk Penelitian Tindakan Kelas berdasarkan masalah yang dihadapi oleh siswa terhadap tata bahasa. Dalam hal ini, penulis menentukan materi yang dipilih dan latihan ke dalam rencana pelajaran. Berdasarkan silabus, ada beberapa jenis penggunaan harus dalam berbagai konteks. Harus bisa mengungkapkan kewajiban dan larangan. Menurut Azzar (1989) harus mengungkapkan gagasan bahwa sesuatu itu perlu. Larangan mengungkapkan gagasan bahwa sesuatu tidak diperlukan. Dalam rencana pelajaran, itu dirancang untuk membandingkan menggunakan keharusan dan tidak harus dalam kewajiban dan larangan. Media pengajaran digunakan seperti power point dan video percakapan. Para siswa membuat diskusi kelompok dan akhirnya, para siswa mempresentasikan hasil diskusi mereka.

Hasil catatan lapangan menunjukkan bahwa pembelajaran telah berjalan dengan baik meskipun kelas masih mengalami beberapa masalah seperti: Pertama, beberapa siswa memiliki masalah dalam mencari kosakata dan tata bahasa yang benar. Kedua, beberapa siswa tampak kesulitan mengikuti kegiatan kelas. Ketiga, 
beberapa siswa terlihat kurang serius dan beberapa siswa masih mengalami kesulitan dalam tata bahasa,

Hasil posttest 1 menunjukkan bahwa skor rata-rata kelas berasal 54,84yang ada 9 siswa yang lulus Kriteria Ketuntasan Minimal (KKM) 78. Data menunjukkan bahwa skor rata-rata posttest 1 adalah. Hanya ada sembilan siswa atau 28,12\% dari siswa yang mendapat skor di atas Kriteria Ketuntasan Minimal (KKM) sementara 19 lainnya siswa berada di bawah kriteria itu. Ini menyiratkan bahwa kriteria pertama tidak terpenuhi.

Berdasarkan hasil test siswa dalam siklus 1, ada sedikit peningkatan nilai rata-rata siswa dari tulisan siswa pada studi awal untuk menulis siswa pada siklus pertama. Nilai rata-rata dari skor sebelumnya adalah 44,68 dan skor rata-rata tata bahasa siswa pada siklus pertama adalah 54,82. Itu berarti ada $10,14 \%$ peningkatan skor rata-rata.

\section{Temuan Siklus II}

Siklus II dilakukan pada pada 19 September, 24 September dan 1 Oktober 2018. Setelah mencerminkan proses belajar mengajar siklus 1, penulis dan guru memutuskan untuk melakukan siklus berikutnya. Untuk mendapatkan hasil yang lebih baik di siklus berikutnya, penulis memodifikasi rencana pelajaran sebelumnya untuk membuat siswa lebih antusias dan lebih aktif selama proses belajar mengajar. Dalam hal ini, penulis memutuskan untuk menggunakan situasi dan video berbasis konteks, gambar dan dialog dalam rencana pelajaran berikutnya. Diharapkan, dengan menggunakan situasi dan video berbasis konteks, gambar dan dialog, para siswa dapat memahami materi modal bantu verba dengan mudah.

Pada pertemuan pertama, para siswa membuat grup yang terdiri dari 5 siswa. Siswa mengamati video untuk mengidentifikasi penggunaan harus dalam memberikan saran. Para siswa mengajukan pertanyaan kepada guru jika ada masalah yang mereka temukan. Guru menjelaskan tentang pola kalimat yang mereka temukan dalam video dan siswa menganalisis pola kalimat berikutnya. Kemudian, siswa memberikan situasi yang digabungkan dengan gambar dan menentukan respon berdasarkan situasi dan akhirnya siswa melakukan tugas 
mereka. Pertemuan kedua, para siswa bekerja berpasangan dan guru memberi situasi kontekstual dan membuat dialog. Setelah menyelesaikan diskusi mereka, para siswa melakukan dialog di depan kelas. Pertemuan ketiga, siswa melakukan posttest 2 dan post-kuesioner.

Peneliti menyimpulkan bahwa penggunaan gambar memberikan pengaruh yang baik bagi siswa, mereka tidak memerlukan waktu yang lama dalam membuat kalimat dialog karena mereka dibantu oleh gambar, guru berbicara agak cepat dalam menjelaskan materi, itu sebabnya siswa bisa mendapatkan pemahaman yang jelas tentang materi. Kemudian, terkait dengan respon siswa pengamat mengatakan bahwa siswa lebih aktif dalam proses belajar mengajar, meskipun ada beberapa siswa yang masih malu dalam mengungkapkan ide-ide mereka.

Berdasarkan hasil perhitungan post test II, nilai rata-rata siswa dalam adalah 80,93. Itu berasal dari:

$$
\begin{aligned}
& \overline{\mathrm{X}}=\frac{\sum x}{n} \mid \\
& X=\frac{2590}{32} X 100 \\
& X=80.93 \%
\end{aligned}
$$

Kemudian, perhitungan persentase kelas tentang siswa yang lulus Kriteria Ketuntasan Minimal (KKM)

$$
P=\frac{F}{N} X 100 \%
$$

$$
\begin{aligned}
& P=\frac{23}{32} X 100 \% \\
& P=71.87 \%
\end{aligned}
$$

Akhirnya, perhitungan persentase peningkatan diperoleh dari rumus berikut: 


$$
\begin{aligned}
& \mathrm{P}=\frac{Y_{2}-Y}{Y} X 100 \% \\
& \mathrm{P}=\frac{80,93-44,68}{44,68} X 100 \% \\
& P=81.13 \%
\end{aligned}
$$

Berdasarkan hasil test tata bahasa siswa, ada peningkatan yang lebih baik dari nilai rata-rata siswa di awal belajar di siklus kedua. Skor rata-rata untuk yang post test I adalah 44,68dan nilai rata-rata posttest 2 adalah 80,93. Itu berarti ada $36,25 \%$ peningkatan skor rata-rata. Para siswa yang lulus KriteriaKetuntasan Minimal (KKM)23 siswa atau 71,87\% jika dihitung dalam persentase kelas target penelitian telah tercapai.

Secara singkat dapat dipaparkan bahwa nilai rata-rata siswa sebelum PTK adalah44,68 . itu berarti persentase kelas yang lulus KKM adalah 12,5\%. Dengan kata lain, dari 32 siswa, hanya ada 4 siswa yang dapat lulus KKM (78) dan 28 siswa lainnya tidak sesuai target. Selanjutnya, nilai rata-rata siswa posttest 1 adalah 54,84.Hal ini menunjukkan peningkatan skor siswa dari pretest yaitu 10,14 atau 22,69\%. Sementara itu, persentase kelas yang lulus KKM I posttest 1 adalah 28,12\%. Itu berarti ada 9 siswa yang lulus KKM dan 23 siswa yang nilainya masih di bawah KKM. Meski hasilnya terlihat lebih banyak perbaikan, tetapi masih dibutuhkan perbaikan untuk mencapai target keberhasilan penelitian, yaitu $70 \%$ dari persentase kelas atau setidaknya bisa mencapai KKMKemudian, pada siklus kedua nilai rata-rata siswa posttest 2 adalah 80,93. Hal ini menunjukkan peningkatan dari posttest $1(80,93$ - 44,68) atau peningkatan siswa 36,25\% dalam persentase skor dari pretest atau peningkatan siswa 22,16\% dari posttest 1 . Selanjutnya, persentase kelas yang lulus KKM adalah 72,22\%, dengan kata lain ada 23 siswa yang lulus KKM dan 9 siswa lainnya masih di luar target. Persentase kelas menunjukkan peningkatan $36,25 \%(80,93$ - 44,68) dari pretest atau 22,16\% $(80,93-54,84)$ dari posttest 1 . Berdasarkan perhitungan itu, dapat dikatakan bahwa posttest II telah berhasil mencapai target yaitu lebih dr 70\% siswa lulus KKM.

Selain hasil test, kesimpulan yang sama juga didapat setelah menganalisa hasil kuesioner. Kuesioner pasca tindakana dilakukan untuk mengetahui tentang 
respon siswa setelah belajar tata bahasa melalui pengajaran dan pembelajaran kontekstual. Peneliti menemukan peningkatan yang signifikan pada respon siswa terhadap proses belajar mengajar. Sebagian besar siswa merasa termotivasi dalam belajar modal bantu kerja Should dan Must setelah pelaksanaan pembelajaran kontekstual dalam proses belajar mengajar. Motivasi tinggi siswa secara otomatis mempengaruhi pemahaman mereka terhadap kata kerja modal bantuShould dan Must. Sebagian besar dari mereka dapat mengingat kata kerja bantu modal should dan Must lebih mudah daripada sebelumnya. Selain itu, kemampuan siswa dalam melakukan latihan modal bantushould dan Must menunjukkan peningkatan yang baik. Selain itu, siswa menyadari bahwa proses belajar mengajar lebih baik daripada sebelum pelaksanaan pembelajaran kontekstual (CTL). Sejalan dengan hasil penelitian ini, Satriani, Emilia \& Gunawan (2012) menemukan CTL membantu siswa mengembangkan kemampuan struktur skematik dan grammar. Bahkan, Yusmalinda (2017) menemukan bahwa CTL mampu meningkatkan kemampuan siswa dalam integrated skills termasuk didalamnya kemampuan penggunaan grammar yang baik.

Para akademisi telah banyak menemukan bahawa cara terbaik belajar bahasa adalah dengan melibatkan strategi Pembelajaran Kontekstual (CTL). Strategi ini membantu siswa menghubungkan kontenpengetahuan dengan konteks aplikasi. Johnson (2006) menyatakan siswa dpat memproses informasi baru dengan cara yang masuk akal bagi mereka karena cocok dalam bingkaireferensi mereka.Dalam lingkungan pembelajaran CTL, siswa menemukan makna hubungan antara ide abstrak dan aplikasi praktis di dunia nyatakonteks. Siswa menginternalisasi konsep melalui penemuan, penguatan, danhubungan timbal balik. CTL mendorongpendidik untuk merancang lingkungan belajar yang menggabungkan banyak bentuk.

Dalam penelitian ini, siswa banyak dilibatkan untuk terlibat secara aktif. Hal ini sesuai dengan yang diamati beberapa peneliti bahwa di ruang kelas CTL, siswatidak bergantung pada guru merekasepanjang waktu, tidak hanya menunggu instruksi, persetujuan, koreksi, saran atau pujian (Widyaningrum, 2013) 
melainkan aktif dalam berpikir kritis (Nawas, 2018), bertindak dan mengambil keputusan.

Selain itu, CTL menyebabkanketerlibatan siswa dalam kegiatan interaksi. Dalam penelitian ini siswa dilibatkan untuk bekerja secara berkelompok, melakukan dialog dan mengerjakan tugas bersama dengan teman-teman mereka. Arifin (2018) juga menemukan bahwa partisipasi siswa juga dinyatakan meningkat setelah pelaksanaan CTL. Hal ini disebabkan karena siswa paham dengan konsep yang diajarkan karena dibantu dengan situasi-situasi atau konteks Selain partisipasi Khaefiatunnisa (2015) menemukan bahwa motivasi siswa dalam belajar Bahasa Inggris juga meningkat. Siswa memiliki morivasi leabih tinggi, mereka mau terlibat dalam berbagai ragam interaksi.Penggunaan CTL dalam ragam interaksi juga dikemukakan oleh Breen dan Candlin (1980) dan Doherty \&Singh (2005). Dengan demikian, akan lebih bijaksana untuk mengklaim bahwa peran siswadiruang kelas CTL adalah fitur yang dinamis dan karenanya cenderung bervariasi setiap saat untuk mencapai hasil yang diinginkan.

\section{SIMPULAN DAN SARAN-SARAN}

Setelah pelaksanaan Penelitian Tindakan Kelas, penulis akan menjelaskan beberapa kesimpulan terkait dengan hasil tindakan. Peneliti juga ingin memberikan saran berkenaan tentang bagaimana melakukan proses pembelajaran yang lebih efektif menggunakan CTL

Berdasarkan hasil penelitian ini dapat disimpulkan bahwa Contextual Teaching and Learning (CTL) dapat meningkatkan pemahaman siswa tentang kata kerja bantu moda should dan Must dalam berbagai konteks.

Pada bagian ini, penulis ingin memberikan beberapa saran untuk dipertimbangkan oleh guru bahasa Inggris

Pertama, guru harus kreatif dalam menciptakan kegiatan belajar mengajar, guru harus fokus pada strategi belajar mengajar tidak hanya fokus pada mentransfer informasi. Kedua, Pengajaran dan Pembelajaran Kontekstual (CTL) adalah metode yang tepat untuk meningkatkan kemampuan siswa dalam berbagai konteks terutama modal bantu 'harus' dan 'harus' Jadi, penulis berharap guru 
menjaga penggunaan Contextual Teaching and Learning (CTL) dalam mengajar modal bantu kerja 'harus' dan 'harus' atau materi tata bahasa lain di tahun ajaran baru berikutnya

\section{REFERENSI}

Arifin, R. 2018. The Implementation of Contextual Teaching Learning (CTL) In Teaching Speaking at the Second Grade of SMK Persada Bandar Lampung. Unpublished thesis, Universitas Lampung

Arikunto, S. 2009.Penelitian Tindakan Kelas. Jakarta: Bumi Aksara.

Azzar, B. S. 1989. Understanding and Using English Grammar: 3rd Edition. New Jersey: Prentice Hall Regents.

Berns, R. G. \& Erickson, P. M. 2001. Contextual teaching and learning: Preparing students for the neweconomy. The Highlight Zone Research@Work, 5.

Doherty, C., \& Singh, P. 2005. How the West is done: simulating western pedagogy in a curriculum for Asian international students. In P. Ninnes\& M. Hellsten (Eds.), Internationalising Higher Education (pp. 53-73). Hong Kong: comparative education research centre, the University of Hong Kong

Jhonson, E. B., 2006. Contextual Teaching and Learning: what it is and why it's hereto stay, California: Corwin Press, Inc, 2006.

Jones, L. 2007. The student-centred classroom. Cambridge: Cambridge University Press.

Khaefiatunnisa. 2015. The Effectiveness of Contextual Teaching and Learning in Improving Students' Reading Skill in Procedural Text(A QuasiExperimental Study of the Second Grade Students at One Vocational School in Bandung).Journal of English and Education, 3(1), 80-95.

Nawas, A. 2018. Contextual Teaching And Learning (CTL) Approach Through React Strategies On Improving The Students' Critical Thinking In Writing. International Journal of Management and Applied Science, 4 (7): 46-49

Nurhadi. 2004.Pembelajaran Kontekstual (Contextual Teaching and Learning) danPenerapannya Dalam KBK. Malang: Universitas Negeri Malang. 
Ruhimat, T. 2012. Kurikulum dan Pembelajaran (Edisi 2). Rajawali Pers: Jakarta.

Satriani, I, Emilia, E. Gunawan, H 2012. Contextual teaching and learning approach to teaching writing. DOI : 10.17509/ijal.v2i1.70

Santrock, J.W. 2002. Life-span Development. (Alih bahasa: Achmad Husairi \& Juda Damanik) Jakarta: Erlangga

Swan, M. 1982. Practical English Usage. Oxford: Oxford University Press, 1982.

Ur, Penny, Grammar Practice Activities: A Practical Guide For Teachers. New York: Cambridge University Press, 1988.

Widyaningrum, A. 2013. Contextual Teaching and Learning (CTL) in ELT English Language Teaching. Diakses di http://download.portalgaruda. org/article.php? article $=110131 \& \mathrm{val}=553$

Yusmalinda. 2017. The Implementation of Contextual Teaching and Learning (CTL) in the Teaching of Integrated Skills. Language Litera, 2(2). 